Акушерство та гінекологія

УдК 618.175-092-02:616.36-002.2

®Л. Є. Лимар, Н. А. Лимар

ДВНЗ « Тернопільський державний медичний університет імені I. Я. Горбачевського МOЗ України»

КЗ ТОР ТОКПЦ«Мати і дитина»

\title{
ДЕЯКІ АСПЕКТИ ПАТОГЕНЕЗУ РОЗЛАДІВ МЕНСТРУАЛЬНОЇ ФУНКЦІї ПРИ ХРОНІЧНИХ ГЕПАТИТАХ (ХГ)
}

ДЕЯКІ АСПЕКТИ ПАТОГЕНЕЗУ РОЗЛАДІВ МЕНСТРУАЛЬНОЇ ФУНКЦІЇ ПРИ ХРОНІЧНИХ ГЕПАТИТАХ (ХГ). ПрОбЛЕМа розладів менструальної функції впродовж тривалого часу турбує науковий світ. Розлади менструальної функції часто зустрічаються у жінок з екстрагенітальними захворюваннями, тому нас зацікавило поглиблене вивчення ланок патогенезу цієї патології. В наш час значною мірою зростає захворюваність на хронічні гепатити (ХГ). Оскільки печінка відіграє визначальну роль у метаболізмі гормонів в організмі жінки, вивчення їх рівня при вказаній патології видається дуже важливим. Нами проведена експериментальна частина роботи, а саме: змодельований токсичний гепатит у статевозрілих самиць білих щурів, вивчені результати морфологічних змін у гіпофізі, яєчниках, матці, печінці, а також результати гормональних та біохімічних досліджень у піддослідних тварин. Вивчені результати клінічних, ехографічних, ендокринологічних, імунологічних досліджень у жінок 3 розладами менструальної функції на тлі ХГ. Обстежено 68 жінок репродуктивного віку з розладами менструальної функції, які хворіють на хронічні гепатити.

НЕКОТОРЫЕ АСПЕКТЫ ПАТОГЕНЕЗА НАРУШЕНИЙ МЕНСТРУАЛЬНОЙ ФУНКЦИИ ПРИ ХРОНИЧЕСКИХ ГЕПАТИТАХ (ХГ). Проблема нарушений менструальной функции на протяжении длительного времени беспокоит научный мир. Нарушения менструальной функции часто встречаются у женщин с экстрагенитальными заболеваниями, поэтому нас заинтересовало углубленное изучение звеньев патогенеза этой патологии. В наше время значительно возрастает заболеваемость хроническими гепатитами (ХГ). Поскольку печень играет определяющую роль в метаболизме гормонов в организме женщины, изучение их уровня при указанной патологии является очень важным. Нами проведена экспериментальная часть работы, а именно: смоделирован токсический гепатит у половозрелых самок белых крыс, изучены результаты морфологических изменений в гипофизе, яичниках, матке, печени, а также результаты гормональных и биохимических исследований у подопытных животных. Изучены результаты клинических, эхографических, эндокринологических, иммунологических исследований у женщин с нарушениями менструальной функции при ХГ. Обследовано 68 женщин репродуктивного возраста с изменениями менструальной функции, страдающих ХГ.

SOME ASPECTS OF PATHOGENESIS MENSTRUAL FUNCTION IN CHRONIC HEPATITIS (CH). Science's world is agitating by problem of menstrual dysfunction during along time. The menstrual dysfunctions often meet in women with extragenital pathology, then profound investigation of the parts of pathogenesis of this pathology is interesting reproductive age's women conduct to the serious problems. The chronic hepatitis increases now. Research of hormonal changes is very important, because liver has important role in hormonal metabolism in women's organism. Experimental part of work made. Toxic hepatitis in white rats is modeling. The results of morphologic, ultramicroscopic changes in hypophisis, ovarium, uterus, liver were studying. The results of hormonal, byochemical research in experimental rats were studying. The results of clinic, sonographic, hormonal, immunological examinations in women with menstrual dysfunction and chronic hepatitis were studying. 68 reproductive age's women with menstrual dysfunction and chronic hepatitis were examining.

Ключові слова: розлади менструальної функції, аномальні маткові кровотечі, олігоменорея, хронічний гепатит.

Ключевые слова: нарушения менструальной функции, аномальные маточные кровотечения, олигоменорея, хронический гепатит.

Key words: menstrual dysfunction, abnormal uterine bleeding, oligomenorrhea, chronic hepatitis.

ВСТУП. Проблема захворювань, зумовлених ендокринними порушеннями, займає одне з провідних місць у гінекологічній практиці. Захворюваність на ці хвороби, за даними багатьох авторів, сягає 60 $65 \%$. Розлади менструальної функції проявляються аномальними матковими кровотечами (АМК), дисменореєю, олігоменореєю і є однією з основних причин втрати працездатності, оскільки супроводжуються кровотечами, анемізацією, больовим синдромом та призводять до зниження якості життя [1, 2]. Незважаючи на значну кількість лікарських засобів, не завжди спостерігається достатній лікувально-про- філактичний ефект, особливо при супутній екстрагенітальній патології [1, 3-9]. Часте поєднання порушень менструальної функції з ХГ взаємно посилює клінічні прояви захворювань, призводячи до втрати працездатності, що спонукає науковців до пошуку нових ланок патогенезу та адекватного лікування даної патології [3-9].

Метою нашого дослідження було вивчити зміни в компетентних органах самиць білих щурів при експериментальному токсичному гепатиті, зміни гормональних та біохімічних показників при цій патології, а також стан гормонального статусу та показників 


\section{Акушерство та гінекологія}

функції печінки, їх кореляцію з клінічними проявами у жінок репродуктивного віку з розладами менструальної функції на тлі хронічних гепатитів.

МАТЕРІАЛИ ТА МЕТОДИ. Експериментальний токсичний гепатит викликався шляхом застосування чотирихлористого вуглецю. Обстежено 40 статевозрілих самиць білих щурів. Проведено патогістологічне дослідження яєчників, матки, печінки та гіпофіза при токсичному гепатиті у піддослідних тварин. Визначені показники фолітропіну, лютропіну, пролактину, естрадіолу, прогестерону. Нами обстежено 68 жінок з порушеннями менструальної функції на тлі ХГ, які були розподілені на 2 групи. До 1 групи ввійшли 30 жінок, у яких спостерігалось загострення ХГ протягом останніх 2 місяців, до 2 групи - 38 жінок, у яких протягом року не було загострення ХГ. Контрольну групу склали 30 соматично здорових жінок [1, 2]. Запропонована нами терапія включала циклодинон по 40 крапель 1 раз на день протягом 3 місяців та гестагенний препарат ендометрин інтравагінально двічі на добу впродовж 2 фази менструального циклу. Всім пацієнткам проводилось клінічне обстеження, УЗД геніталій, органів черевної порожнини, загальноприйняте лабораторне обстеження: клінічне дослідження крові, сечі, визначення глюкози, білірубіну, холестерину, білка, сечовини, креатиніну, трансаміназ: аланінамінотрансферази (АЛаТ), аспартатамінотрансферази (АСаТ), у-глутаматтрансферази (ГГТ), лужної фосфатази (ЛФ) в крові. Гормональні дослідження проводили з допомогою імуноферментного методу, визначали рівень фолітропіну, лютропіну, пролактину, естрадіолу, прогестерону. Статистичну обробку отриманих даних виконано у відділі системних статистичних досліджень ДВН3 «Тернопільський державний медичний університет ім. І. Я. Горбачевського МОЗ України» в програмному пакеті StatSoft STATISTICA.

РЕЗУЛЬТАТИ ДОСЛІДЖЕННЯ ТАЇХ ОБГОВОРЕННЯ. Патогістологічне дослідження яєчників у самиць статевозрілих щурів при експериментальному токсичному гепатиті виявило різке зменшення розмірів та субтотальну деструкцію фолікулярного апарата. В матці виявлені дистрофічні зміни в ендометрії. У 16 самиць $(80,0 \%)$ виявлена атрофія ендометрія. Патогістологічне дослідження печінки виявило жирову дистрофію та заміщення сполучною тканиною паренхіми у 18 (90,0 \%) піддослідних тварин. Дослідження гіпофіза виявило дистрофічні зміни в аденогіпофізі, відсутність залозистої тканини, аденоматоз у 13 (65,0 \%) самиць. Гормональні дослідження виявили різке зниження у порівнянні з контролем фолітропіну, лютропіну, естрадіолу та прогестерону. Середній вік обстежуваних жінок склав у досліджуваних групах 28,3 і 29,6, у контрольній - 27,6 року. У 22 (73,3 \%) пацієнток 1 групи спостерігався хронічний невірусний гепатит, у 8 (26,7 \%) - хронічний вірусний гепатит, у 26 $(68,4 \%)$ пацієнток 2 групи - хронічний невірусний гепатит, у 12 (31,6 \%) - хронічний вірусний гепатит. Хронічні гепатити спостерігались від 2 до 6 років. У пацієнток обох груп загострення вказаних захворювань були пропорційними. Серед клінічних проявів розладів менструальної функції спостерігались наступні порушення: аномальні маткові кровотечі (AMK) у $8(26,7 \%)$ жінок 1 групи та 32 (84,2\%) жінок 2 групи, олігоменорея у $19(96,7 \%)$ жінок 1 групи та у 4 $(10,5 \%)$ жінок 2 групи, дисменорея (больовий синдром під час менструації у всіх пацієнток 1 та 2 груп; головний біль у 22 (73,3\%) жінок в 1 групі та у 26 $(68,4 \%)$ пацієнток 2 групи, мастодинія у 27 (90,0\%) жінок у 1 групі і в 32 (84,2 \%) у 2 групі, нерегулярні менструації - $12(40,0 \%)$ в 1 групі та $23(60,5 \%)$ у 2 групі. Виявлені ознаки захворювання підтверджують літературні дані $[1,2]$. Середня тривалість гінекологічного захворювання в 1 і 2 групах коливалась від 3 до 8 років. Контрольне обстеження жінок проводилось через 6 і 12 місяців. Показники гормонального статусу виявились наступними: у пацієнток 1 групи рівень фолітропіну в 1 фазу спостерігався в межах $(11,38+4,16) \mathrm{MO} / л ;$ в 2 групі - $(13,12 \pm 3,71) \mathrm{MO} / л$ ( $>0,05)$ проти $(6,11 \pm 2,56) \mathrm{MO} / л$ у контрольній групі. Лютропін становив $(12,26 \pm 2,34) \mathrm{MO} / л$ і $(14,18 \pm$ $2,32) \mathrm{MO} / л(p>0,05)$ відповідно в 1 та 2 групах проти $(15,21 \pm 1,76) \mathrm{MO} / л$ у контрольній групі, що відповідає літературним показникам [1, 2]. Показник естрадіолу в цих пацієнток у 1 фазу визначався в межах $(73,29 \pm 9,16) \quad \mathrm{нг/л}(P>0,05)$ і $(83,41 \pm 10,36) \quad \mathrm{Hг/л}$ $(\mathrm{P}<0,05)$ відповідно в 1 і 2 групах проти $(52,21 \pm$ $8,12)$ нг/л у контрольній групі, причому в 2 фазу циклу рівень естрадіолу становив $(65,49 \pm 10,63) \mathrm{Hг/л}$ $(P>0,05)$ і $(73,41 \pm 11,36)$ нг/л $(P<0,05)$, тобто утримувався практично в тих же межах, що і в 1 фазу проти контрольного показника $(32,73 \pm 7,19)$ нг/л. Рівень прогестерону в 1 фазу у пацієнток коливався в межах $(0,87 \pm 0,28)$ мкг/л $(P<0,05)$ і $(0,63 \pm 0,21) \mathrm{Mкг/л}$ $(\mathrm{P}<0,05)$ проти $(3,31 \pm 0,16)$ мкг/л у контрольній групі. В 2 фазу циклу рівень прогестерону становив $(0,76 \pm 0,23)$ мкг/л $(P<0,05)$ і $(0,61 \pm 0,26)$ мкг/л $(P<0,05)$ проти $(12,36 \pm 1,96)$ мкг/л у контрольній групі, тобто залишався практично на рівні показників у 1 фазу і був достовірно нижчим, ніжу контрольній групі. Показники пролактину становили $(20,231 \pm 1,35)$ мкг/л у 1 групі і $(22,17 \pm 1,62)$ мкг/л у 2 групі проти $(8,41 \pm 1,17)$ мкг/л у контрольній групі і протягом всього часу проведення досліджень достовірно не змінювались в обох дослідних групах. Ці результати підтверджують дані літератури $[1,2]$.

Гормональні дослідження через 6 місяців виявили підвищення прогестерону в 2 фазу циклу до $(3,24 \pm 1,18)$ мкг/л у 1 групі та до $(5,16 \pm 1,34)$ мкг/л у 2 групі. Контрольні дослідження через 12 місяців показали, що у 7 (23,3 \%) пацієнток 1 групи рівень прогестерону в 2 фазу знизився до $(1,69 \pm 0,27) \mathrm{мкг/л,}$ відновились прояви дисменореї, спостерігалось підвищення лютропіну до $(23,26 \pm 7,47) \mathrm{MO} / л$, крім цього, в 10 (33,3 \%) пацієнток під час лікування загострились ХГ. Ультразвукове сканування геніталій у жінок 1,2та контрольної груп органічної патології не виявило. УЗД печінки у фазі ремісії змін не виявило, у фазі загострення відмічались ознаки запалення (розмиті контури, збільшені розміри, розширення судин, зернистість паренхіми). Дослідження клінічних, біохімічних показників та маркерів гепатитів B, C у пацієнток 1 групи виявило підвищення рівня загального білірубіну, холестерину, АЛаТ, АСаТ, ГГТ, ЛФ. Показники контрольної групи були достовірно нижчі 


\section{Акушерство та гінекологія}

від досліджуваних груп і відповідали фізіологічній нормі. Після лікування у жінок 1 групи досліджувані біохімічні показники нормалізувались, у 2 групі ці показники залишались підвищеними, що підтверджувалось наявністю клінічного загострення ХГ. Отримані результати відповідають літературним даним $[2,3,5-9]$.

ВИСНОВКИ. Проведені дослідження доводять, що експериментальний токсичний гепатиту статевозрілих самиць білих щурів призводить до виражених змін не лише в печінці, ай в органах репродуктивної

\section{СПИСОК ЛІТЕРАТУРИ}

1. Про організацію надання акушерсько-гінекологічної та неонаталогічної допомоги в Україні. Наказ № 620. - Київ, 2003.

2. Дубоссарская 3. М. Теория и практика гинекологической эндокринологии / 3. М. Дубоссарская. Днепропетровск, 2005. - 409 с.

3. Радченко В. Г. Основы клинической гепатологии / В. Г. Радченко, А. В. Шабров, Е. Н. Зиновьева. СПб., 2005. - 860 с.

4. Ильченко Л. Ю. Хронические вирусные гепатиты: перспективы и достижения / Л. Ю. Ильченко, Г. Н. Якимчук // Экспериментальная и клиническая гастроэнтерология. - 2007. - № 2. - С. 34-38.

5. Загальні етичні принципи експериментів на тваринах. Перший національний конгрес з біоетики, Київ, 2001 р. // Ендокринологія. - 2003. - Т. 8, № 1. C. $142-145$ системи та гіпофізі, що зумовлює різке зниження рівня гонадотропних та статевих гормонів. У жінок репродуктивного віку на тлі ХГ спостерігаються розлади менструальної функції у вигляді АMK, олігоменореї та дисменореї. Виявлені прояви менструальної дисфункції викликані гормональними порушеннями, які зумовлені порушенням функції печінки.

ПЕРСПЕКТИВИ ПОДАЛЬШИХ ДОСЛІДЖЕНЬ. ПЛАнуються подальші дослідження менструальної функції при ХГ та можливість реалізації репродуктивної функції.

6. Короленко Т. А. Субклеточное распределение кислых гидролаз печени крыс при токсическом гепатите / Т. А. Короленко, А. Е. Кондрикова, В. Г. Титова // Бюл. экспер. биол. и мед. - 1975. - Т. LXXX, № 7. C. 35-36.

7. Рикало Н. А. Експериментальна модель хронічного тетрахлорметанового гепатиту та цирозу печінки у нестатевозрілих щурів / Н. А. Рикало // Вісник Української' медичної' стоматологічної' академії. - 2009. T. 9, № 2. - С. 116-118.

8. Lenaerts C. Surveillance for cystic fibrosisassociated hepatobiliary disease:early ultrasound changes and predisposingfactors[Text] / C. Lenaerts, C. Lapierre, H. Patrquin // J. Pediatr. - 2003. Vol. 143. - P. 343-350.

9. Wedemeyer H. Fatty. Liver Disease [Text] / H. Wedemeyer, M. P. Manns.- Conference Report: $38^{\text {th }}$ Annual Meeting of the Europen Association for the Study of the Liver(EASL); Geneva, Switzerland, July 3-6, 2003. 